\title{
CULTURE OF THE PEOPLES OF THE BLACK SEA REGION COUNTRIES IN THE CONTEXT OF THE GLOBAL CULTURE FORMATION IN THE ERA OF GLOBALIZATION
}

\author{
(C) Yulia P. Ten \\ Financial University under the Government of the Russian Federation, \\ Moscow, Russian Federation \\ YPTen@fa.ru
}

The relevance of the appeal to the study of the development of culture on a global scale is due to the fact that in the modern period no people or region or country can exist in isolation. In the face of the latest challenges of globalization (the pandemic, the environmental crisis, the threat of man-made disasters, etc.), all countries must join forces in solving world problems. The author proposes a structural-systematic approach to the analysis of the essence of the phenomenon of culture. Hence, the goal of the research is to analyze culture as a complex structured system. In the article, culture is considered by analogy with the "iceberg culture" model, consisting of different layers. The author's attention is focused on the analysis of the process of forming the upper (world) layer of human culture. This layer of culture is a system of ideas, ideals, knowledge, norms and values that are accepted by most countries of the world. The adoption of this system of meanings of the world culture is an important step towards overcoming intercultural communication barriers. Thus, the author draws attention to the fact that although since ancient times the countries of the Black Sea region have been united by a common cultural history, political and trade and economic ties, nevertheless, barriers for mutual understanding have not been eliminated yet. Therefore, today it is very important that all the peoples realize the need to find ways and technologies to form a common language of the world culture.

Key words: culture, globalization, intercultural communication, barriers of intercultural communication, world culture, multi-level model of culture.

\section{[Ю.П. Тен Культура народов стран Причерноморья в контексте формирования глобальной культуры в эру глобализации]}

Актуальность обращения к исследованию развития культуры в мировом масштабе обусловлена тем, что в современный период ни один народ, регион, страна не могут существовать изолированно. Перед лицом новейших вызовов глобализации (пандемия, экологический кризис, угроза техногенных катастроф и т.д.) все страны должны объединить свои усилия в решении мировых проблем. Автор предлагает структурно-системный подход к анализу сущности феномена культуры. Отсюда целью исследования является анализ культуры как сложно структурированной системы. В статье культура рассматривается по аналогии с моделью «культуры-айсбергом», состоящем из разных ярусов и пластов. Внимание автора сосредоточено на анализе процесса формирования верхнего (мирового) яруса человеческой культуры. Данный ярус культуры представляет собой систему идей, идеалов, знаний, норм и ценностей, которые принимаются большинством стран мира. Принятие данной системы значений и смыслов мировой культуры - важный шаг на пути преодоления межкультурных барьеров коммуникации. Так, автор обращает внимание на тот фракт, что хотя страны Причерноморья с древних времен объединены общей культурной историей, политическими и торгово-экономическими связями, тем не менее барьеры для взаимопонимания до сих пор не устранены. Поэтому сегодня очень важно, чтобы все народы осознали необходимость поиска способов и технологий для фрормирования общезначимого языка мировой культуры.

Ключевые слова: культура, глобализация, межкультурная коммуникация, барьеры межкультурной коммуникации, мировая культура, многоуровневая модель культуры.

Yulia P. Ten - Ph.D. (Advanced Doctorate) in Philosophy, Associate Professor, Financial University under the Government of the Russian Federation, Moscow, Russian Federation. 
Тен Юлия Павловна - доктор философских наук, доцент, Финансовый университет при Правительстве Российской Федерации, г. Москва, Российская Федерация.

\section{Introduction}

In the era of globalization, the interrelation and interdependence of States and regions forming the world community leads to their integration into a unified system with generally accepted patterns, norms and standards of economic, political and socio-cultural behavior. Globalization is a multidimensional process of creating a social community on a planetary scale, with openness and the removal of barriers to the establishment of intellectual, spiritual, ethical and other forms of communication between people. Arjun Appadurai identifies five main "flows" of globalization: people, technology, finance, the media and ideas [4]. By twisting these flows into a kind of "digital vortex," globalization takes culture as a kind of magnetic "conductor" to realize the relationship between individuals, groups and communities of different countries and regions. Hence, the growing interdependence and interinfluence of different ethnic and national cultures is a characteristic feature of the intensification of international interactions.

Interest in culture is due to the uniqueness and multifaceted nature of this phenomenon. Culture is a phenomenon that arose in ancient times and which still illuminates with its light and fills with meaning the existence of humanity on the Earth. Not coincidentally, back in ancient times, many peoples of the Black Sea region (Scythians, Sarmatians, Bulgars, Slavs, etc.) had an idea of the world tree as the center of the Universe. Culture is like a giant tree: the foundations of modern cultures are rooted deep in the roots of this tree (ancient Egyptian culture, ancient Greek culture, etc.). The trunk of the tree forms the historical periods of the past of national cultures (of French, Russian cultures, etc.). And what do young shoots form on the crown of a tree? Of course, the tree is a living organism that develops. In the recent period, the tree forms the upper "layer," which is associated with all the structural elements of this tree. This is due to the fact that peoples, as branches of the tree, are divided among themselves. In recent times, the need to find a common space of meanings for mutual understanding among peoples in the process of intercultural communication is being actualized.

The author's hypothesis consists in the assumption that it is the formation of the common shareable by representatives of different peoples and cultures of the "layer" of meanings of the world culture of mankind will contribute to more effective achievement of mutual understanding between peoples as representatives of different cultures.

Hence, the purpose of this study is formulated, which is to consider culture as a complex structured system in order to identify, describe and analyze features of the formation of the upper (world) layer of human culture.

The multifaceted nature of the problem determines the choice of methods of scientific research. The study is interdisciplinary. Research methods used in the work are comparative analysis and synthesis of various scientific ideas and approaches from social philosophy, cross-cultural management, sociology, the theory of intercultural communication. The complexity of the studied question determines the author's decision to use the method of system-structural analysis of culture.

Culture has always played an integration and consolidation role in human society. However, the cultural diversity of the modern world is so great that the achievement of mutual understanding between peoples is difficult, since various kinds of communicative barriers are on the way to mutual understanding. 
Various communicative barriers are distinguished in science: physiological barriers; language barriers; socio-psychological barriers; behavioral barriers; actually, culturological barriers. Many scientists agree that the most difficult to overcome barriers blocking the resulting quality of cross-cultural communications are high anxiety when faced with a representative of foreign culture, the assumption of similarities, the tendency to evaluate judgments in relation to carriers of foreign culture, ethnocentrism, stereotypes and prejudices, religion, incorrect interpretation of non-verbal means of communication; the language. Despite the existence of barriers, "effective intercultural communication is impossible if we do not perceive barriers to intercultural interaction and do not know how to eliminate them" [5, p.208].

According to M. Redzhev, the process of development of cultural globalization, in its various guises and numerous dimensions, consolidated what we can call the "global cultural infrastructure" [10]. This global cultural infrastructure includes both material and nonmaterial aspects. In essence, globalization legalized the existence of a certain cultural standard, according to which a person of modern society must meet certain requirements in order to communicate in a multicultural environment successfully (speak foreign languages, be able to use the latest messengers, a personal computer, carry out the process of communication with representatives of other cultural worlds, understand the trends in the development of modern art, philosophy, literature, science, etc.) [2, p.43]. Thus, globalization creates the preconditions for culture to move beyond communal tribal and localterritorial entities.

Hence, the scientists are interested in the theme of the formation of a "global," "world," "network," "information" culture. Such an ideal construct can become a real reflection in the practice of modern processes as a result of the intensification of intercultural communications between different subjects of interaction. Hence, the need to construct relations between organizations, countries on the basis of the principles of modernism, pluralism and tolerance, which contribute to the achievement of mutual understanding and coherence of their positions in solving international problems through the dialogue, is formed. The fact is that the world experience shows that the most effective strategy for achieving successful cross-cultural understanding is a dialogue based on the development of a generally significant system of global concepts, categories, ideals, principles, symbols, norms and values. From the author's point of view, it is the formation of a generally significant level of human culture that will contribute to the gradual phased formation of the "upper" ideological and semantic layer of the global culture, the development of which is possible through various types of social institutions (of family, education, science, and international organizations). Only on this path social groups and communities divided by various kinds of barriers will be able to find points of understanding.

\section{The concept of culture as a multi-level system}

First of all, it is necessary to clarify the interpretation of the concept of "culture" through the prism of modern knowledge about this phenomenon.

Culture includes stereotypes of thinking and behavior, common meanings, which members of the same society attribute to different phenomena, natural or artificially created, as well as artifacts, skills and technologies transmitted from generation to generation, as well as broadcast to other cultures in intercultural communications.

Within the framework of this study, in accordance with the purpose of this study, it is advisable to distinguish three aspects of understanding the phenomenon of culture:

1) mentalistic (culture is a collectively programmed thinking that distinguishes representatives of one social community from others); 
2) behavioral (culture is a system of patterns and norms of thinking and behavior of individuals in social community);

3) integrative (culture is the unity of objective and subjective aspects of the cultural existence of social community).

Culture is an ultra-complex structural formation consisting of various components (of knowledge, concepts, ideas, ideals, values, norms, symbols, patterns and technologies). Moreover, culture appears in terms of a system-structural approach as a multi-level system integrity. Thus, in 1960, the classic of cultural anthropology K. Oberg [10] developed a model of iceberg culture. This model consists of visible and invisible parts. The part of the iceberg that rises above the water is a small part of the entire mass of culture. We can see the visible outer surface of the iceberg. However, the hidden parts of culture are more powerful and more difficult to identify. Invisible parts are where the most important elements of culture come from, and they are those that lead to a deeper sense and understanding of culture. E.H. Schein supplemented the measurement of cultures in the form of three layers that reflect the degree of "visibility," that is, comprehensibility, from the visible to the least visible level of culture (from artifacts, further to "proclaimed values" to the comprehension of "basic ideas"). The three-layer model of Schein culture emphasizes the importance of studying culture as a set of components, while understanding more essential components is possible in an evolutionary immersion from the external manifestations of culture to its foundations [3].

It should be noted that culture can be divided by a subject as a representative of a given culture. Thus, the following cultures are distinguished: culture of an individual, culture of a social group, culture of a social (ethnic, national, etc.) community, culture of a social institution (for example, religious culture), culture of organization.

On a global scale, the world civilization can be represented as mega-culture that includes great variety of macro-cultures. Macro-cultures can be classified according to the certain criteria: national (for example, the Russian culture, the Bulgarian culture, the Turkish culture, etc.), geographical (culture of the peoples of the Black Sea region, etc.), confessional (the Christian culture, etc.), economic (culture of post-industrial countries, etc.). Within macro-cultures, there are different micro-cultures (cultures of ethnic minority, diasporas, etc.). In turn, micro-cultures can include various kinds of subcultures and countercultures. An amazing, bright and colorful mosaic of the world culture is created from all this great variety. Thus, it is possible to distinguish the culture of the peoples of the Black Sea region into a certain cluster. This is due to several reasons: geographical proximity, close millennial and centenary trade and economic contacts and ties, as well as spiritual and value ties. At the same time, all the countries of the Black Sea region cannot exist and develop in isolation. Of course, it is important for all peoples and cultures to find common technologies to solve global problems (such as the pandemic, the threat of an environmental crisis, etc.). The formation of a common layer of cultural meanings (ideas, ideals, values, norms, etc.) as the upper layer of culture could help to facilitate mutual understanding between peoples.

The review of the academic literature shows that there are virtually few studies combining the study of cultures with the scope of all the levels. In this regard, the "GLOBE" project should be mentioned, the members of which, in particular, studied charismatic leadership at three nested levels: organizational, sectoral and national. The important contribution to the development of this approach was made by M. Erez and E. Gati [6], who managed to build a dynamic, multilevel model of culture conceptually: from the micro level of the personality to the macro level of the global culture. Let's consider their theoretical and practical proposals, supplemented by the author's comments. 
Culture is a complex multilevel formation that can include, but not limited by them, individual, organizational, and national culture. The level of organizational culture is "nested" in national culture. Organizational culture is often defined as a set of beliefs and values shared by the members of the same organization that affects their behavior [3]. The conceptualization of culture at the individual level reflects cultural values, as they are represented in the culture of the individual.

It is important to clearly indicate the level of analysis when referring to culture, rather than assuming that cultural aspects at one level will be universally applied to all other levels. For example, G. Hofstede concluded that values related to activities within a certain organizational culture should be evaluated at the national level, since the same values may not be applicable in an individual context. Therefore, proclaiming that every Japanese is a collectivist by nature simply because he belongs to the Japanese culture would be a misconception, since the description of the culture and the description of the individual embedded in this culture are two different concepts [8]. This is illustrated by other cultural models [11], where the number of cultural measurements varies depending on the level of assessment (the national level or the individual level).

Culture is multifaceted and can be manifested both in material form (for example, clothing, food, interior design, etc.) and in intangible form (for example, language, values, etiquette, ethics, etc.). Most researchers of the organizational and national levels of culture are particularly interested in values as a key component of culture. Even in G. Hofstede's model of culture as a bulb, these are the values that form the core of this "bulb" [7]. Some scientists believe that the choice of values for the analysis is because values are easier to measure than other cultural aspects, especially from a national perspective. Thus, the researchers [12] found that $97.5 \%$ of measuring instruments proposed by G. Hofstede are viable in the latest period. From Hofstede's perspective, culture at the national level is best explained by five dimensions that rank countries based on their combined estimates of individualism, masculinity, distance of power, avoidance of uncertainty, and long-term orientation. However, care should be taken when creating comparisons between different levels [8].

It is believed that culture is relatively stable. Indeed, there are cases from the world history when cultural values as the cores for the life of a particular social community were the guidelines for the development of culture for centuries and even a millennium (a vivid example is Byzantine culture). However, having entered the era of the Great geographical discoveries, the era of the emergence and development of capitalism, the development and colonization of new territories, in the era of the triumph of science and technology, cultures of different countries and regions were drawn into the titanic mechanism of the emerging and unfolding powerful impulses of globalization. With the beginning of the strengthening and expansion of intercultural communication opportunities, forms and channels, such forms of acculturation as assimilation, separation, organization and integration began to manifest themselves in each context with different strengths and diverse consequences. In the face of the challenges of globalization (threats of man-made disasters, depletion of natural resources, etc.), humanity needs to go on the path of cultural integration in search of "answers", adequate and rational strategic solutions agreed with all actors of cross-cultural communications.

Under the influence of globalization, scientists record changes in the systems of traditional values of modern societies. The analysis of empirical data, led by R. Inglehart and C. Welzel, shows that there are two dimensions of cross-cultural variability in the world: a pair of "traditional" values and "secular-rational" values, as well as a pair of "survival values and "self-expression values". R. Inglehart and C. Welzel developed a "global cultural 
map" model, which illustrates how most modern societies are located in these two dimensions. The upward movement of a given society is a reflection of the shift from traditional values to secular-rational, and the movement to the right demonstrates the movement of society from survival values to self-expression values [1].

Globalization strengthens acculturation processes in most societies. The type of acculturation of countries depends on two factors: the level of attraction to the new global culture and the importance of preserving their own values, that leads to four types of acculturation mentioned earlier: integration, assimilation, separation and marginalization. M. Erez and E. Gati talk about the inevitability of forming a kind of universal "eco-cultural model" in the framework of which acculturation appears as a process of cultural change and adaptation to the new values, both at the level of society and at the individual level. Therefore, M. Erez and E. Gati believe that these are dynamic rather than stable models of culture that should serve to understand the changing environment in response to globalization [6, p.586]. Through the top-down processes of socialization, people absorb a system of common values of a certain society, while maintaining their values at the individual level. Then, through the bottom-up processes of aggregating common values, there is an ascent to a higher level. In an effort to meet the challenges of globalization, each subject of culture is involved in the process of forming a "world," "network," "information," "global" culture. Thus, cultural actors are formed at the group, organizational and national levels of a multi-layered system. Thus, the multilevel culture model defines the boundaries in which bottom-up processes can become a higher-level formation. The relationship between topdown and bottom-up processes suggests that the macro level of culture affects the micro level of individual self-assessment [6].

So, the structure-system approach allows us to present culture as an ultra-complex structural formation, consisting of various kinds of components (knowledge, concepts, ideas, ideals, values, norms, symbols, patterns). Here, culture is interpreted as a multilayer formation. In the process of intercultural communication, the interaction subject begins the process of understanding another culture based on his initial ideas about the external level of a contacting culture. But the deeper he seeks to penetrate the essence of foreign culture, the more he begins to realize the cultural differences of contacting cultures. The ability to overcome various kinds of barriers (linguistic, psychological, social-behavioral and other) in the process of intercultural communication of representatives of different peoples is due to the degree of difference between the actors of interaction. Although since ancient times the countries of the Black Sea region have been united by a common cultural history, political and trade and economic ties, nevertheless, barriers for mutual understanding have not been eliminated yet. To overcome communicative barriers, intercultural communication actors must expand and develop intercultural competence. At the same time, intercultural competence involves the development of knowledge and ideas about someone else's culture from the lower surface level to the lower level of foreign culture in stages.

Cross-cultural communication can provide a "platform" for individuals, social groups and communities to communicate, harmonize and coordinate their actions in terms of developing a generally relevant algorithm for solving international problems of a global nature. The upper layer of culture, presented as a system of ideas, ideals, knowledge, norms and values, should be constructed as a result of intercultural communications of modern peoples. The adoption of this system of meanings of the world culture is an important step towards overcoming intercultural communication barriers. Therefore, today it is very important that all peoples realize the need to find ways and technologies to form a generally significant "stratum" of the world culture. 
This study is one of the steps towards a deeper study of the transformation of modern world culture, which is an inevitable response to the challenges of globalization.

\section{Лumepamypa}

1. Инглхарт P. Культурная эволюция: как изменяются человеческие мотивации и как это меняет мир / пер. с англ. С.Л. Лопатиной. М.: Мысль, 2018.

2. Мамедов, Н.М. Глобализация как современное состояние общественного развития // Эпоха глобальных перемен (опыт фрилософрского осмысления). М., 2004.

3. Шейн Э.Х. Организационная культура и лидерство / пер. с англ. под ред. В.А. Спивака. СПб: Питер, 2002.

4. Appadurai $A$. Disjuncture and difference in the global cultural economy // Theory, Culture \& Society. 1990. Vol. 7. Issue 2-3. P. 295-310.

5. Braslauskas J. Effective creative intercultural communication in the context of business interaction: theoretical and practical aspects // Creativity studies. Vol. 13. No 1. 2020.

6. Erez M., Gati E. A dynamic, multi-level model of culture: from the micro level of the individual to the macro level of a global culture // Applied Psychology: an international review. 2004. N 53 (4). P. 583-598.

7. Hofstede G. Culture's consequences: international differences in work-related values. Beverly Hills, 1980.

8. Kwantes $C$.

9. T., Glazer S. Culture, organizations, and work: Clarifying concepts. N.Y.: Springer, 2017.

10. Oberg K. Culture shock: adjustment to new cultural environments // Practical Anthropology. 1960. № 7. P. 177-82.

11. Regev M. Postlude: world culture after cultural globalization // Poetics. 2019. Vol. 75.

12. Schwartz, S.H. A theory of cultural values and some implications for work // Applied Psychology: an international review. 1999. N48 (1). P. 23-47.

13. Taras V., Kirkman B.L., Steel P. Examining the impact of culture's consequences: A three-decade, multilevel, meta-analytic review of Hofstede's cultural values dimensions // Journal of Applied Psychology. 2010. N 95(3). P. 405-439.

\section{References}

1. Inglehart R. Kulturnaia evoliutsiia: kak izmeniaiutsia chelovecheskie motivatsii i kak eto meniaet mir. Per. s angl. S.L. Lopatinoi. [Cultural evolution: how human motivations change and how it changes the world. Translated from English by S.L. Lopatina]. Moscow: Mysl, 2018 (in Russian).

2. Mamedov, N.M. Globalizatsiia kak sovremennoe sostoianie obshchestvennogo razvitiia. Epokha globalnykh peremen (opyt filosofskogo osmysleniia). [Globalization as a modern state of social development. The era of global changes (experience of philosophical reflection)]. Moscow, 2004 (in Russian).

3. Schein E.H. Organizatsionnaia kultura i liderstvo. Per. s angl. pod red. V.A. Spivaka. [Organizational culture and leadership. Translated from English. Under the editorship of V.A. Spivak]. Saint Petersburg: Peter, 2002 (in Russian). 
4. Appadurai A. Disjuncture and difference in the global cultural economy. Theory, Culture \& Society. 1990. V. 7. Issue 2-3, pp. 295-310.

5. Braslauskas J. Effective creative intercultural communication in the context of business interaction: theoretical and practical aspects. Creativity studies. V. 13. No. 1. 2020.

6. Erez M., Gati E. A dynamic, multi-level model of culture: from the micro level of the individual to the macro level of a global culture. Applied Psychology: an international review. 2004. No. 53 (4), pp. 583-598.

7. Hofstede G. Culture's consequences: international differences in work-related values. Beverly Hills, 1980.

8. Kwantes C. T., Glazer S. Culture, organizations, and work: Clarifying concepts. New York: Springer, 2017.

9. Oberg K. Culture shock: adjustment to new cultural environments. Practical Anthropology. 1960. No. 7, pp. 177-82.

10. Regev M. Postlude: world culture after cultural globalization. Poetics. 2019. V. 75.

11. Schwartz, S.H. A theory of cultural values and some implications for work. Applied Psychology: an international review. 1999. No. 48 (1), pp. 23-47.

12. Taras V., Kirkman B.L., Steel P. Examining the impact of culture's consequences: A three-decade, multilevel, meta-analytic review of Hofstede's cultural values dimensions. Journal of Applied Psychology. 2010. No. 95(3), pp. 405-439. 